\title{
Product Part Active Ingredient Indicator
}

National Cancer Institute

\section{Source}

National Cancer Institute. Product Part Active Ingredient Indicator. NCI Thesaurus. Code C94027.

Specifies whether the ingredient is an active ing redient. 